\title{
El ejército y la definición de sus principios constitucionales. Obediencia y no deliberación política en Chile, 1829-1830*
}

\begin{abstract}
Alejandro San Francisco
Profesor del Instituto de Historia y de la Facultad de Derecho de la Pontificia Universidad Católica de Chile (Chile), investigador del Instituto de Historia de la Universidad San Sebastián (Chile). Correo electrónico: asanfran@gmail.com El autor es doctor en Historia por la Universidad de Oxford (Inglaterra). Entre sus publicaciones recientes está la obra de la cual es Director general: Historia de Chile 1960-2010. Tomo 5 y 6. Las vías chilenas al socialismo. El gobierno de Salvador Allende (Santiago, Universidad San Sebastián/ CEUSS, 2019). Entre sus temas de interés se encuentran Historia política de Chile, Historia militar, Historia de los conceptos.
\end{abstract}

Recibido: 30 de marzo de 2019

Aprobado: 10 de noviembre de 2019

Modificado: 20 de noviembre de 2019

Artículo de investigación científica

DOI: http://dx.doi.org/10.15648/hc.36.2020.10

* Este artículo forma parte del proyecto “¿Obediencia y no deliberación? El Ejército y la presencia política de los militares en Chile, 1818-1841" financiado por Comisión Nacional de Investigación Científica y Tecnológica-CONICYT, a través del Proyecto FONDECYT 1095204

Esta publicación está bajo una licencia Creative Commons Reconocimiento-NoComercial 4.0 
El ejército y la definición de sus principios constitucionales. Obediencia y no deliberación política en Chile, 1829-1830

\title{
Resumen
}

Este artículo estudia la definición constitucional del ejército de Chile, los principios de obediencia y no deliberación militar en la guerra civil de 1829, cuando se enfrentaron dos formas de comprender esa fórmula: algunos militares defendieron al gobierno, mientras otros se sublevaron contra él, argumentando que las autoridades habían violado la constitución.

El estudio concluye que, si bien había unidad en torno a esos principios en términos teóricos, la comprensión práctica de los mismos era contradictoria, lo que fue decisivo para el estallido de la guerra y para la formación del nuevo orden constitucional en Chile.

Palabras clave: Ejército-militarismo-obediencia militar-deliberación política

Army and the definition of its constitutional principles. Obedience and non- political deliberation in Chile, 1829-1830

\begin{abstract}
This article deals with the Chilean Army principles of obedience and non-military deliberation during the 1829 civil war, when two interpretations of these principles were confronted: some soldiers supported the government meanwhile others rebelled against it, arguing that the authorities had violated the constitution.

The study concludes that, although there was unity around these principles in theoretical terms, the practical understanding of them was contradictory, which was decisive for the outbreak of war and for the creation of a new constitutional order in Chile.
\end{abstract}

Key words: Army-militarism-military obedience-political deliberation.

O exército e a definição de seus princípios constitucionais. Obediência e deliberação não política no Chile, 1829-1830

Resumo

Este artigo estuda a definição constitucional do exército do Chile, os princípios de obediência e deliberação não militar na guerra civil de 1829, quando duas formas de 
entender essa fórmula foram enfrentadas: alguns militares defenderam o governo, em quanto outros se revoltaram contra ele, argumentando que as autoridades haviam violado a constituição. $\mathrm{O}$ estudo conclui que, embora houvesse união em torno desses princípios em termos teóricos, o entendimento prático deles era contraditório, o que foi decisivo para a eclosão da guerra e para a formação da nova ordem constitucional no Chile.

Palavras-chave: Exército-militarismo-militar obediência-deliberação política

\section{L'armée et la définition de ses principes constitutionnels. Obéissance et non délibération politique au Chili, 1829-1830}

\section{Résumé}

Cet article étudie la définition constitutionnelle de l'armée du Chili, les principes d'obéissance et de délibération non militaire dans la guerre civile de 1829, lorsque deux moyens de comprendre cette formule ont été confrontés: des militaires ont défendu le gouvernement, d'autres se sont révoltés contre lui, arguant que les autorités avaient violé la constitution. L'étude conclut que, même s'il existait une unité théorique autour de ces principes, leur compréhension pratique était contradictoire, ce qui a été déterminant pour le déclenchement de la guerre et la formation du nouvel ordre constitutionnel au Chili.

Mots-clés: Armée, militarisme, obéissance militaire, délibération politique.

\section{INTRODUCCIÓN}

En la primera mitad del siglo XIX -especialmente desde 1810 en adelante- Chile vivió un proceso progresivo de formación de instituciones propias del gobierno republicano, con las ilusiones que ello implicaba, pero también con las dificultades y deficiencias que fueron tradicionales en el continente y en las diversas naciones que surgieron de la emancipación respecto de la corona castellana ${ }^{1}$.

1 Para el caso chileno y la política de la Independencia se pueden ver, entre otros, Jaime Eyzaguirre, Ideario y ruta de la emancipación chilena (Santiago: Editorial Universitaria, 24 ${ }^{\mathrm{a}}$ edición [1957, $1^{\mathrm{a}}$ edición], 1996); Sergio, Villalobos, Tradición y reforma en 1810 (Santiago: RIL editores, $2^{\mathrm{a}}$ edición, 2006); Simon Collier, Ideas y política de la Independencia chilena, 1808-1833 (Santiago: Editorial Andrés Bello, 1977); Alfredo Jocelyn Holt, La Independencia de Chile. Tradición, Modernización 
El presente trabajo analiza la presencia de los militares en política, especialmente en torno a la guerra civil de 1829-1830. Chile ha sido definido como una "tierra de guerra" para el siglo XIX, cuando cada generación debió enfrentar un conflicto interno o internacional, desde la Independencia hasta fines de siglo. ${ }^{2}$ En esa centuria, varias guerras civiles enfrentaron a distintos sectores de la sociedad chilena, por razones políticas o constitucionales, luchas por el poder, querellas regionalistas o forma última de resolver una crisis institucional ${ }^{3}$.

El análisis se hace a partir de la historia política, militar y del derecho, considerando, en primer lugar, el contenido de las normas constitucionales en la década de 1820, que fijaron en los distintos textos la obediencia militar a las autoridades civiles y el principio de no deliberación; a continuación, se analiza la acción práctica de los uniformados, que en ocasiones contrastaba con dichas normas. Finalmente, el texto se concentra en la guerra civil que enfrentó a dos ejércitos en una contienda decisiva, en la que no sólo lucharon en los campos de batalla, sino también en el plano jurídico y doctrinal, sosteniendo posturas contradictorias sobre la forma cómo debía ser interpretada la obediencia y no deliberación militar. La discusión siguió después de la guerra, involucrando tanto la obediencia a las autoridades políticas como una visión más compleja que implicaba la subordinación al régimen constitucional en su conjunto. De esta manera, desde una perspectiva histórica, el tema adquiere valor no sólo por lo que dicen las constituciones, sino también por la interpretación práctica de los preceptos específicos so-

y Mito (Santiago: Planeta - Ariel, 1999); Julio Heise, Años de formación y aprendizaje políticos 1810-1833 (Santiago: Editorial Universitaria, 1978); Juan Ricardo Couyoumdjian (Coord.) y Joaquín Fermandois (Dir.), Chile. Crisis imperial e independencia, Tomo 1 1808/1830 (Madrid: Fundación Mapfre - Taurus, 2010); Eduardo Cavieres, Sobre la independencia en Chile. El fin del Antiguo Régimen y los orígenes de la representación moderna (Valparaíso: Ediciones Universitarias de Valparaíso 2012); Fernando Silva, Historia de la República de Chile 1808-1826. Volumen 1. El fin de la monarquía y los orígenes de la república (Santiago: Zig Zag, 2013); Javier Infante, Autonomía, independencia y república en Chile 1810-1828 (Santiago: Centro de Estudios Bicentenario, 2014).

2 El concepto es utilizado por Mario Góngora, Ensayo histórico sobre la noción de Estado en Chile en los siglos XIX y XX (Santiago, Editorial Universitaria, 1986), 29.

$3 \mathrm{Al}$ respecto, se puede consultar el reciente trabajo de Joaquín Fernández, "Las guerras civiles en Chile”, en Iván Jaksic y Juan Luis Ossa Historia política de Chile, 1810-2010. Tomo I. Prácticas políticas (Santiago: Fondo de Cultura Económica, 2017), 53-82. 
bre los militares en momentos de grave crisis y división. Esto alteraba la pretensión chilena de mayor estabilidad institucional.

Una de las razones por las que Chile habría sido diferente a las demás naciones se dio en la participación de los militares en actividad política, diferencia que se expresó especialmente a partir de 1830. Se ha sostenido que Chile constituyó una excepción en el siglo XIX en el contexto iberoamericano, porque logró consolidar el gobierno civil y la vigencia del régimen constitucional, además de prevenir el desarrollo del militarismo, como han enfatizado en sus estudios Edwin Lieuwen, John Johnson y Alain Rouquié 4 . Por otra parte, Miguel Ángel Centeno ha vuelto sobre esta misma idea en su estudio sobre las guerras que hubo en el continente en sus dos siglos de vida independiente ${ }^{5}$. En su clásico estudio sobre los caudillos, John Lynch también ha defendido esta misma postura, argumentando que Chile estuvo ajeno al caudillismo característico de la región debido a su capacidad de crear un sistema adecuado de sucesión presidencial. ${ }^{6}$ Para la década de 1830, Bernardino Bravo Lira afirma que uno de los pilares de la excepcionalidad chilena fue el pronto sometimiento de los militares al poder civil, proceso en el que Portales jugó un rol gravitante, porque "puso fin al militarismo [y] el Ejército volvió a estar al servicio de la patria y a ser el principal apoyo del gobierno"7. Parte de esto fue posible gracias al establecimiento de la llamada Guardia Cívica, uno de cuyos objetivos era precisamente hacer frente a las iniciativas militares contra el orden establecido ${ }^{8}$. Con ello, sin embargo, se formaba una nueva instancia que valoraba al ciudadano-soldado, lo que volvía a reconocer la existencia de un riesgo objetivo de que continuara la presencia militar en política.

4 Edwin Lieuwen, Arms and politics in Latin America (New York: Frederick A. Praeger, 1960); John Johnson, The military and society in Latin America (Stanford: Stanford University Press, 1964) y Alain Rouquié, El estado militar en América Latina (Buenos Aires: Emecé, 1984).

5 Miguel Ángel Centeno, Blood and debt: war and the nation-state in Latin America (University Park, Penn State University Press, 2002).

6 John Lynch, Caudillos en Hispanoamérica 1800-1850 (Madrid: MAPFRE, 1993).

7 Bernardino Bravo Lira, "Portales", en Portales, el hombre y su obra: la consolidación del gobierno civil, comp. Bernardino Bravo Lira (Santiago: Editorial Jurídica de Chile, 1989), 339.

8 Roberto Hernández Ponce, "La Guardia Nacional de Chile. Apuntes sobre su origen y organización 1808-1848”, Historia № 19 (1984), 53-114, y Joaquín Fernández, "Los orígenes de la guardia nacional y la construcción del ciudadano-soldado (Chile, 1823-1833)", Mapocho, Nº 56 (2004). 
Estas aseveraciones han permitido generar una imagen sobre Chile, y una autoimagen, que destaca esta trayectoria constitucional. Tan temprano como en 1834 el cónsul británico Mr. White señalaba casi con orgullo que Chile era un país "donde se podía comenzar a disfrutar la estabilidad institucional, a diferencia de otras naciones del continente, que seguían sufriendo la anarquía y la revuelta". Por su parte, al finalizar el primer gobierno bajo la Constitución de 1833, el periódico de gobierno El Araucano sostenía que Chile era "la excepción honrosa de paz y estabilidad, de orden y libertad", que contrastaba con "los desórdenes de la anarquía y de las demasías del poder arbitrario que afligen a la mayor parte de los estados Hispanoamericanos"10.

Sin embargo, aunque ambas apreciaciones cuentan con cierto soporte en los hechos, también eluden un aspecto fundamental: el gobierno del general Joaquín Prieto (1831-1841), había nacido -al igual que la Constitución de 1833- como fruto de la división política, se originó por medio de un levantamiento militar y por el triunfo en una guerra civil. Es decir, nació a partir de una intervención de los uniformados en la actividad política, derrotando en los campos de batalla a otra forma de ver la realidad institucional a fines de la década de 1820. Ambos sectores se encontraban unidos a grupos civiles que compartían sus posturas.

La afirmación, sin duda, estaba marcada por el cambio que se había producido a partir de 1830, cuando ya se había iniciado el gobierno "pelucón” y, por primera vez en mucho tiempo, una administración duraba varios años y tenía perspectivas de continuar dirigiendo al país. En la década anterior había ocurrido exactamente lo contrario, con numerosos cambios gubernativos y dificultades para asegurar la continuidad de las constituciones o de las administraciones que se suponía guiarían a Chile hacia la consolidación republicana. El tema adquiere importancia, considerando que el país vivía -al igual que las otras naciones del continente- una etapa de lucha por una legitimidad política posterior a la monarquía y de redefinición de los vínculos que unían a los pueblos

9 White a Foreign Office (Valparaíso, 27 de mayo de 1834), Archivo del Foreign Office, FO 16/23, № 15.

10 El Araucano (9-4-1841). 
con sus autoridades políticas y sus constituciones, tarea que fue difícil y que tuvo avances y retrocesos ${ }^{11}$.

Es preciso considerar que tanto la experimentación política como el militarismo presente en varios momentos después de 1810 no fueron una exclusividad chilena, sino que se enmarcan en un ambiente mayor -referido a todo el continente americano- de esfuerzos muchas veces fallidos por encontrar fórmulas más duraderas de gobernabilidad, así como de lograr el establecimiento del gobierno civil.

Para el constitucionalismo, y para la historia política y del derecho constitucional, se trata de un tema de la mayor importancia teórica y práctica. Este es un tema internacional, no exclusivamente, local: como sostiene Miguel Artola, la policía y las fuerzas armadas existían para el mantenimiento del orden y para enfrentar eventuales guerras. En el ámbito interno, debían servir para hacer frente a movimientos sediciosos o levantamientos contra el orden institucional ${ }^{12}$.

En el plano de la relación de los uniformados con el poder político, Chile ha tenido dos bases fundamentales para la primacía de la subordinación democrática, como sostienen Montes y García. En primer lugar, las tradiciones y creencias presentes en el común de los civiles y militares, que indican que sin subordinación civil no es posible la vigencia de un sistema democrático; en segundo lugar, el influjo efectivo de la consagración de variados medios de mando de las autoridades del mundo civil sobre las Fuerzas Armadas, tanto en la Constitución como en las leyes ${ }^{13}$.

Por lo mismo, cobra relevancia estudiar aquellos soportes doctrinarios y políticos a partir de los cuales se configuró tanto la prescindencia política como la participación del Ejército en las actividades de gobierno.

11 Juan Luis Ossa, "Revolución y construcción republicana en Chile, 1810-1851”, en Historia política de Chile, 1810-2010. Tomo I. Prácticas políticas, Iván Jaksic y Juan Luis Ossa (Santiago: Fondo de Cultura Económica, 2017), 36-43.

12 Miguel Artola, Constitucionalismo en la historia (Barcelona, Crítica, 2005), 211-214.

13 Gonzalo García y Juan Esteban Montes, Subordinación Democrática de los militares. Éxitos y fracasos en Chile (Santiago: Centro de Estudios del Desarrollo, 1994), 56. 
El texto sugiere que la guerra civil de 1829 fue un momento clave para definir la comprensión de los deberes militares, tanto desde el punto de vista teórico como en el orden práctico, manifestándose posturas contradictorias muy claras en este último caso, con respaldo civil y militar para ambas posiciones.

\section{El EjÉRCito y LAS DEFINICIONES CONSTITUCIONALES: EL DERECHO}

El factor militar comenzó a ser relevante en tanto se inició el proceso de Independencia, y pronto fue necesario abordar la naturaleza constitucional de la función del Ejército. Sin embargo, también es preciso tener en cuenta la continuidad que tuvo la institución respecto del ejército de la monarquía e incluso muchos de los uniformados que ingresaron a la vida militar antes de 1810 continuaron en ella bajo las nuevas circunstancias políticas después de la formación de las juntas de gobierno.

Tan temprano como en 1811 un documento emanado de la Junta Provincial de Concepción había resumido el mismo principio al declarar: "las tropas son esencialmente obedientes, y no deliberan sino en unión de la masa general de ciudadanos". En esa misma ocasión resumía lo que podríamos denominar el principio rector de la relación Ejército y política, destinada a ser una guía maestra para las siguientes décadas de organización republicana:

"Sería un error de cálculo imperdonable el persuadirse que un puñado de soldados puede, en ningún evento, ser árbitro de la suerte del reino, alterar a su arbitrio el gobierno, y mucho menos trastornarlo. La fuerza armada, cualquiera que sea, pudiera triunfar por momentos del pacífico y desarmado ciudadano; pero la opresión no podría durar por largo tiempo"14. en Sesiones de los Cuerpos Legislativos de la República de Chile 1811 a 1845 (Santiago: Imprenta Cervantes, 1887), Tomo I, pp. 205-207. Sobre el contexto de este momento y doctrina, ver Armando Cartes, Concepción contra Chile. Consensos y tensiones regionales en la Patria, 229-266. 
Un par de años después Juan Egaña reflexionaba sobre el asunto, en un contexto en el que estimaba necesario "impedir la prepotencia militar en las revoluciones"15. Para el jurista el militarismo era un peligro para la estabilidad institucional y una violación directa del principio de la supremacía civil a través de la fuerza militar ${ }^{16}$. De esta manera, procuró que la Constitución de 1823, de la cual fue autor, estableciera claramente el gobierno civil y la subordinación militar.

Así, la carta fundamental señalaba en su artículo 226: “La fuerza pública es esencialmente obediente: ningún cuerpo armado puede deliberar"17. Se trataba de una fórmula escueta y clara, que provenía del constitucionalismo francés -en su Constitución de 1791-, como ha precisado Alejandro Guzmán Brito ${ }^{18}$. En cuanto a las funciones militares, el artículo 225 señalaba que existía una doble misión: "mantiene la seguridad interior y la defensa exterior" 19 .

Adicionalmente, el texto establecía algunas limitaciones al Poder Ejecutivo en materias militares: prohibía que el Director Supremo fuera simultáneamente comandante en Jefe del Ejército, así como efectuar nombramientos o ascensos militares en grado superior al de teniente coronel. Para Javier Infante se trataba de "la primera tentativa de separación entre el mando civil o político y el mando militar" 20 . Valentina Verbal, en tanto, destaca que las elites civiles tuvieron "una abierta vo-

15 Carta de Juan Egaña a José Miguel Carrera, 17 de febrero de 1813, en Cristóbal García-Huidobro y Javier Infante, Muy señor mío... Un epistolario de Juan Egaña Risco 1801-1833 (Santiago: Historia Chilena, 2016), 39. Sin perjuicio de esto, otros intelectuales valoraban la noción de lo que podríamos llamar "ciudadano armado" o la necesidad de que la sociedad tuviera una formación militar: incluso el primer periódico nacional destaca que Grecia clásica comenzó a decaer "cuando los ciudadanos ricos, que habían perdido la fortaleza varonil por los placeres y el ocio, distinguieron las funciones militares de las civiles, abandonaron las armas, y se contentaron con contribuir a los gastos de la guerra". Ver Aurora de Chile, No 26, jueves 6 de agosto de 1812.

16 Valentina Verbal, "Las relaciones civiles-militares en Chile bajo la Constitución 1823. Una explicación de sus disposiciones y contexto político”, Derecho Público Iberoamericano, 7 (2015), 159-199.

17 Constitución Política del Estado (1823) art. 226.

18 Alejandro Guzmán Brito, "El constitucionalismo revolucionario francés y las cartas fundamentales chilenas del siglo XIX”, en La Revolución Francesa y Chile, eds. Ricardo Krebs y Cristián Gazmuri (Santiago: Editorial Universitaria, 1990), 225-245.

19 Constitución Política del Estado (1823) art. 225.

20 Javier Infante, Autonomía, independencia y república en Chile 1810-1828, 239-240. 
luntad por combatir el militarismo radical, las insubordinaciones castrenses destinadas a deponer gobiernos o disolver congresos"21.

Efectivamente antes de esta fecha -por la primacía de Bernardo O’Higgins-, e incluso en los años siguientes, por la incapacidad de establecer una forma estable de gobierno, la separación entre la actividad política y la militar fue solamente ocasional, y no parte de una forma institucional.

\section{LOS MILITARES EN LA ACTIVIDAD POLÍTICA: LOS HECHOS}

Entre 1810 y 1851 existió una presencia permanente de uniformados en la actividad política de Chile. Con más precisión, esta situación llevó a que altos oficiales del Ejército tuvieran funciones de gobierno o en el Congreso Nacional, además de ejercer una deliberación política más o menos constante.

Así, la independencia nacional estuvo marcada por figuras como Bernardo O’Higgins y José Miguel Carrera; la década de 1820 tuvo algunos representantes muy influyentes, como Ramón Freire y Francisco Antonio Pinto; finalmente, los dos primeros presidentes que completaron sus períodos e incluso fueron reelegidos -Joaquín Prieto y Manuel Bulnes- extendieron su presencia entre 1830 y 1851. Como factor relevante, todos ellos fueron militares cuya acción en el ámbito castrense significó después la consolidación de un liderazgo político. En la primera etapa, como ha explicado Juan Luis Ossa, se unieron los ejércitos, la política y la revolución ${ }^{22}$.

Es preciso considerar que tanto la experimentación política como el militarismo presente en varios momentos no fueron una exclusividad de Chile, sino que se enmarcan en un ambiente mayor -referido a todo el continente americano- de esfuerzos, muchas veces fallidos, por encontrar fórmulas más duraderas de gobernabilidad. Por lo mismo la presencia militar no era una simple imposición de las armas, sino que

21 Valentina Verbal, "Las relaciones civiles-militares en Chile bajo la Constitución 1823. Una explicación de sus disposiciones y contexto político", 190.

22 Juan Luis Ossa, Armies, politics and revolution. Chile, 1808-1826 (Liverpool: Liverpool University Press, 2014). 
muchas veces contaba con la adhesión o participación de los civiles que reconocían dicha supremacía o liderazgos. Por otra parte, el liderazgo militar resulta ser el correlato político, incluso heroico, del triunfo en los campos de batalla.

Para el caso chileno Simon Collier ha afirmado que la participación de algunas figuras militares relevantes del siglo XIX chileno -como fueron Bernardo O’Higgins, Ramón Freire, Joaquín Prieto y Manuel Bulnes-, deben interpretarse como contribuciones a la consolidación del régimen republicano y no de otra manera, como podría sugerir el carácter castrense de esos líderes $^{23}$. Durante el siglo XIX la presencia de uniformados en servicio activo en la vida política del país fue continua y se manifestó en áreas muy diversas. Desde la década de 1830 en adelante -con antecedentes claros en los años previos- destacados uniformados ocuparon desde la Presidencia de la República hasta cargos locales como intendentes de las provincias, pasando por la representación parlamentaria en la Cámara de Diputados o en el Senado ${ }^{24}$.

¿Existió el riesgo del militarismo en esos años? "Si se entiende como control de los militares sobre los civiles", el proceso tiene connotaciones de ambigüedad ${ }^{25}$. Sin embargo, el concepto puede ser comprendido en un doble sentido. En primer lugar, se refiere a un hecho, la primacía o preponderancia militar en el gobierno de un Estado. En segundo término, señala una doctrina o actitud mental, como sería propiciar la presencia militar en las actividades políticas de una sociedad ${ }^{26}$. Julio Heise afirma que Chile estuvo ajeno a este problema en los años de organización de la república, sin embargo también es cierto que en los primeros treinta años de vida independiente la presencia militar fue continua tan-

23 Simon Collier, "Cuatro hombres de armas en la formación y la consolidación de la República", en Patriotas y ciudadanos (2004) 16-38.

24 Luis Valencia, Anales de la República (Santiago: Editorial Andrés Bello, 1986); Enrique Fernández, "La institucionalidad jurídico-política chilena entre 1831 y 1931: las bases de su estabilidad", Jahrbuch für Geschichte Lateinamerikas, 40 (2003), 258-260; Sergio Vergara, Historia Social del Ejército de Chile (Santiago: Universidad de Chile, 1993), Vol. I, 191-193. tteucci y Gianfranco Pasquino (Madrid: Alianza Editorial, 2007), 963.

26 Bernardino Bravo Lira, "Gobiernos civiles y gobiernos castrenses en Iberoamérica. 1810-1992", Sociedad y Fuerzas Armadas, 5-6 (1992), 19. 
to en los hechos como en las invitaciones que los civiles les formulaban para dirimir una determinada situación política en uno u otro sentido ${ }^{27}$.

Gabriel Salazar ha enfatizado la existencia de un "militarismo ciudadano" en la década de 1820, liderado por el general Ramón Freire, con el objetivo de derribar a la dictadura de O'Higgins. Al respecto ha precisado que "sería un error considerar a los militares del período 1810-1829 como meros soldados, a los políticos como meros operadores civiles, a los ciudadanos como meros individuos con o sin derecho a voto, y al proceso histórico que vivieron como un período normal y funcional, donde los soldados debían ser sólo soldados, los políticos sólo políticos y los ciudadanos sólo una masa expectante". Salazar concluye insistiendo en que la "soberanía popular estaba constituida por la unión vital e histórica del ciudadano, el político y el soldado" 28 .

Como argumentan Mc Evoy y Cid, la actuación política de los militares estaba legitimada por la figura de "ciudadano en armas", que era una imagen que "facilitaba el recurso a la figura del militar como tutor de la política y catalizador de la voluntad popular", especialmente "cuando aparecía en el horizonte la fragilidad del orden republicano" ante el riesgo de las facciones ${ }^{29}$.

El resultado de esta doble militancia, de ciudadano soldado, se manifestó en el liderazgo de José Miguel Carrera y Bernardo O’Higgins en los años de la emancipación; de Ramón Freire y Francisco Antonio Pinto en la década de 1820; y la irrupción de Joaquín Prieto a fines de esos años. Adicionalmente, la discusión sobre la politización militar se trasladó a otros niveles, como ocurrió con la politización del Ejército en el Congreso Nacional ${ }^{30}$.

27 Julio Heise, Años de formación y aprendizaje políticos 1810/1833, 129-134.

28 Gabriel Salazar, Construcción de Estado en Chile (1800-1837). Democracia de los “pueblos". Militarismo ciudadano. Golpismo oligárquico (Santiago: Editorial Sudamericana, 2005), 458.

29 Carmen Mc Evoy y Gabriel Cid, "El republicanismo en Perú y Chile: derroteros y desafíos de un proyecto en América del Sur, 1810-1895”, en América Latina de la Independencia a la crisis del liberalismo 1810-1930, Volumen V, eds. Nuria Tabanera y Marta Bonaudo (Zaragoza, Marcial Pons/ Prensas de la Universidad de Zaragoza, 2016), 328.

30 Juan Luis Ossa, Armies, politics and revolution. Chile, 1808-1826, 204-213. 
A esto se sumaba un aspecto de origen diferente, pero que cuenta con relevancia histórica, como es que en la década de 1820 Chile experimentó numerosos casos de rebelión, motines militares y diversas manifestaciones de descontento y deliberación militar, lo que generaba una situación permanente de dificultades gubernamentales, cambios de administración y crisis políticas de distinto tipo. Las motivaciones para estos movimientos eran muchas: falta de pago a los soldados, otros problemas propios de las instituciones, algunos liderazgos caudillescos al interior del Ejército, manifestaciones específicas de participación política. Así ocurrieron las intervenciones de Enrique Campino en 1826, de unos batallones de infantería ese mismo año y de Pedro Urriola en 1827. Como afirman Julio Pinto y Verónica Valdivia, "ambos motines militares eran una toma de partido", lo dos tenían vínculos con los federalistas, desconocían a las autoridades existentes y utilizaron la fuerza, aunque finalmente fueron indultados. Era una "deliberación política militar" expresa ${ }^{31}$.

El problema de fondo radica, sin embargo, en otro asunto. Si Freire u otro militar se levantaba contra un gobierno, porque este era considerado dictatorial o no respetaba los derechos de las provincias, los argumentos de dicha rebelión, aunque pudieran ser más o menos plausibles, indudablemente se apartaban de inmediato del principio de obediencia (ciega) constitucional y se introducían en los caminos de la deliberación militar. Así había ocurrido en 1823 contra O’Higgins y la Constitución de 1822, y así sucedería en 1829, por el problema de las elecciones bajo la Constitución de 1828.

Por esto, no basta con constatar los hechos -la deliberación militar o su intervención en los sucesos políticos- sino que es necesario precisar en función de qué principios o normas jurídicas se da esta participación en el ámbito público, si ello es parte de un derecho o bien de una violación de las obligaciones militares.

31 Julio Pinto y Verónica Valdivia, ¿Chilenos todos? La construcción social de la nación (1810-1840) (Santiago: Lom Ediciones, 2009), 281. 
En este sentido debe analizarse la recurrencia de los uniformados a la dirección política del país. A veces, incluso, se habían levantado contra el gobierno de turno e intentaban generar un cambio político de importancia, incluso la promulgación de una nueva constitución, lo que en ocasiones lograron. Este fenómeno se producía a pesar de que la tendencia de los documentos constitucionales se dirigía a restringir la actividad política de los militares, circunscribiéndolos a las actividades propias de la defensa nacional.

\section{LA GUERRA CIVIL DE 1829: LA GÉNESIS}

En 1828 Chile tuvo una nueva Constitución, que pareció iniciar una etapa más positiva de organización republicana, y que superaría los ensayos constitucionales precedentes ${ }^{32}$.

En términos políticos había un gran entusiasmo y esperanzas hacia el futuro. Como resumió a comienzos de 1829 el representante norteamericano en Chile, "la nueva Constitución continúa encontrando la aprobación de la gente en todas las partes de la república, y todo indica que será sostenida y llegará a ser permanente"33. La explicación de Sam Larned era consistente con la visión de las autoridades chilenas. El propio texto de la Carta Fundamental decía que había llegado "el día solemne de la consolidación de nuestra libertad..."34.

Francisco Ramón Vicuña, presidente del Senado y Vicepresidente provisorio, leyó el mensaje de apertura del Congreso Nacional en septiembre de 1829, destacando la nueva etapa que vivía Chile: "nuestra patria goza de un reposo perfecto; el espíritu público rechaza con indignación cuanto puede turbarlo, y las pequeñas diferencias de opinión, frutos necesarios de toda transformación política, van extinguiéndose poco

32 Una obra tradicional y muy valiosa sobre el tema es Federico Errázuriz, Chile bajo el imperio de la Constitución de 1828 (Santiago: Imprenta Chilena, 1861).

24833 Sam Larned a Henry Clay (Santiago, 29 de marzo de 1829), en United States of America, State Department, Washington D. C., Dispatches From United States Minister To Chile, 1823-1906, Nº 80.

34 La referencia en el "Mensaje del Vicepresidente de la República a la nación, en Constitución de 1828”, en Constitución Política de la República (1828), 9-8. 
a poco en las relaciones de la vida social y desapareciendo de un todo bajo la sombra protectora y conciliadora del pacto que nos une"35.

La historia marchó en sentido contrario, en parte como fruto de la misma constitución que se valoraba. La ocasión de la crisis provino de las elecciones para Presidente y Vicepresidente de la República, que se verificaron con normalidad, pero que produjeron la división posterior.

De acuerdo a la Constitución de 1828, los electores debían votar por dos nombres. El Presidente de la República sería el ciudadano que obtuviera la mayoría absoluta, y el Vicepresidente quien lograra la segunda mayoría absoluta. En la ocasión participaron 201 personas en calidad de miembros del cuerpo electoral (compuesto de 216 en total). Para la Primera Magistratura no hubo inconvenientes: Francisco Antonio Pinto obtuvo una amplia mayoría, con 122 votos, siendo electo como Presidente de la República.

El problema se produjo para la elección de Vicepresidente, ya que ninguno de los candidatos obtuvo la votación necesaria. En la ocasión, los resultados fueron los siguientes: Francisco Ruiz Tagle, cercano a la oposición, obtuvo 100 votos; el militar Joaquín Prieto, de tendencia o’higginista, logró 61 votos; Joaquín Vicuña, quien contaba con el apoyo liberal, logró 48 votos; José Gregorio Argomedo obtuvo 33 sufragios y también hubo otros votos dispersos ${ }^{36}$. En tal circunstancia, la Constitución de 1828 señalaba que correspondía al Congreso elegir "entre los de la mayoría inmediata” (art. 72), con la presencia de tres cuartos de los miembros de las cámaras al menos.

No es necesario reproducir todo el proceso de crisis de interpretación constitucional, pero sí dejar claro aquello que se vincula a la intervención militar que derivaría del problema. La oposición consideraba que la elección de Vicepresidente debía recaer en Ruiz Tagle o Prieto.

35 El mensaje de Francisco Ramón Vicuña, Sesión del 13 de septiembre de 1829, en Sesiones de los Cuerpos Legislativos de la República de Chile, 1811 a 1845, Tomo XVIII (1897) 60-65.

36 Diego Barros Arana, Historia Jeneral de Chile (Santiago: Josefina M. de Palacios, Editora, 1897), Tomo XV, 368-376. 
El tema era relevante y estaba vinculado a Pinto, que había manifestado su intención de renunciar a la Primera Magistratura, lo que dejaría despejado el camino hacia el gobierno al que obtuviera la segunda mayoría. Mientras los conservadores estimaban que el cargo debía recaer en algunas de las dos primeras mayorías relativas, es decir, Ruiz Tagle y Prieto, los liberales sostenían que la decisión correspondía al Congreso, donde ellos tenían mayoría. El resultado fue el siguiente: Joaquín Vicuña obtuvo 29 votos y Francisco Ruiz Tagle 24 (también hubo dos votos para Prieto y tres en blanco). Como ninguno obtuvo mayoría absoluta, se pidió una nueva votación, pero la mayoría del Congreso rechazó la propuesta y proclamó a Joaquín Vicuña como Vicepresidente de la República, vulnerando el sentido de la norma de elección de dicha autoridad. Las elecciones no condujeron a la tranquilidad política, sino a una nueva etapa de turbulencias, al existir una crisis de legitimidad del poder político y del orden constitucional vigente en el país a lo que se sumó la división militar y la guerra civil.

Para sumar otros problemas, el general Francisco Antonio Pinto no aceptó el cargo para el cual había sido electo, como ya lo había anticipado. Sin duda estaba agotado por los enfrentamientos políticos y con el ejercicio del mando, en un contexto de repetidas crisis ${ }^{37}$. Los intentos para que revirtiera su decisión no prosperaron, y la acefalía presidencial debía ser llenada precisamente por el cuestionado Vicepresidente Vicuña. En palabras de Pinto, algunas acciones del Congreso tenían "un vicio de ilegalidad”, por lo que no podía asumir la Primera Magistratura. Propuso, a su vez, "la separación absoluta del Congreso, la convocación de los cuerpos electorales y la renovación de las elecciones constitucionales para el año venidero" "38. Su proposición, como era previsible, no fue aceptada por el poder legislativo: quedaba abierto el camino de la rebelión. Los partidarios del gobierno, convencidos de su legitimidad y apoyo social, no estaban dispuestos a renunciar; la oposición consideraba ilegítima la victoria de los gobernantes. Como ambos tenían respaldo militar, eso marcó el comienzo de la guerra civil.

37 Juan Luis Ossa, "La actividad política de Francisco Antonio Pinto: 1823-1828. Notas para una revisión biográfica", Historia, 40, 1 (2007), 91-128.

38 "Renuncia del General Francisco Antonio Pinto a la Presidencia de la República", 18 de octubre de 1829, en Sesiones de los Cuerpos Legislativos, Tomo XIX, Anexo N 150, p. 159. 
¿Qué deber tenía el ejército en una situación como esta? ¿Cuál era la regulación específica de sus deberes constitucionales? La Constitución de 1828 había establecido muy claramente el tema, siguiendo la tendencia de la época y que quedaría registrada en el constitucionalismo chileno. El capítulo XI, "De la fuerza armada", trataba muy escuetamente el tema militar, en dos artículos: "Artículo 123.- La Fuerza Armada se compondrá del Ejército de mar y tierra, y de la Milicia activa y pasiva. El Congreso, en virtud de sus atribuciones, reglará el número, orden, disciplina y reemplazo, tanto del Ejército como de la Milicia, cuyo régimen debe ser uniforme. Artículo 124.- Todo chileno en estado de cargar armas, debe estar inscrito en los registros de la Milicia activa o pasiva, conforme al reglamento" 39 .

A esto se sumaban otras atribuciones en materia castrense, en que el Presidente de la República requería el acuerdo con el Poder Legislativo, expresión del sello más parlamentario de la Carta Fundamental: proveer ciertos empleos militares (que requería acuerdo del Senado para los coroneles y demás oficiales superiores del ejército permanente), o la declaración de guerra (que exigía una resolución previa del Congreso Nacional) ${ }^{40}$.

Sin embargo, el asunto práctico era más complejo que la mera obediencia pasiva a una determinada disposición constitucional, especialmente porque era uno de aquellos casos en los cuales se ponía en duda la misma carta fundamental que establecía las normas sobre temas militares, y también porque los actores políticos buscaban en los uniformados un apoyo a sus posturas para la resolución del conflicto político y de confusión o conflicto constitucional ${ }^{41}$. Era un doble proceso de politización del ejército y militarización de la política.

39 Constitución Política de la República (1828).

40 Ver Valentina Verbal, "Las fuerzas armadas en la Constitución de 1828. Una explicación desde las relaciones civiles-militares”, Revista Ensayos Militares, 1, 2 (2015), 179-191.

41 Dentro de la doctrina política de las Fuerzas Armadas, la posibilidad de dejar la obediencia pasiva y asumir una posición de árbitros en un conflicto constitucional ha sido destacada por Felipe Agüero, "Autonomy of the Military in Chile: From Democracy to Authoritarianism", en Augusto Varas, Democracy Under Siege. New Military Power in Latin America (New York-London: Greenwood Press, 1989), 83-96. Ver también Alejandro San Francisco, "Los militares y la política en Chile republicano. Dos siglos con contradicciones, intervenciones y constituciones", Anales del Instituto de Chile. Es- 
La división política se manifestó al concluir el proceso electoral. El Congreso decidió proclamar al general Francisco Antonio Pinto como Presidente de la República y Joaquín Vicuña como Vicepresidente. Posteriormente Pinto renunció a su cargo, lo que fue rechazado por la Cámara de Diputados, que invocó el patriotismo de Pinto: el general mantuvo su posición, en un ambiente que marchaba al despeñadero, o al borde del precipicio, como diría el propio Pinto al deponer el mando en favor de Francisco Ramón Vicuña, Presidente del Senado ${ }^{42}$.

Como en otros casos en la década de 1820, el primer levantamiento surgió desde las provincias, donde todavía existían algunos problemas pendientes, que formaban parte del proceso de independencia y de organización republicana ${ }^{43}$. En Chillán se reunieron numerosos jefes del ejército chileno, quienes rechazaron las decisiones emanadas de las Cámaras en Valparaíso. ${ }^{44}$ En primer lugar, aquellos soldados apoyaron la decisión de la Asamblea de Concepción que condenaba el nombramiento del Vicepresidente de la República, "con infracción sustancial de la Constitución". Por lo mismo, el ejército se vio en la obligación de proteger esa decisión, en cuanto contribuía a proteger la libertad política y las leyes fundamentales del país, así como se oponía a los riesgos del despotismo. Adicionalmente, el documento de los militares aseguraba someterse al Poder Ejecutivo, en cuanto fuera "restablecido el poder constitucional transgredido". La proclama señala que el ejército no depondría "su presente actitud de protestar de los derechos nacionales ultrajados, hasta tanto que obtengan la reparación compatible con su dignidad". El texto se transmitía a la Asamblea de Concepción y a quienes se acogieran "en defensa de la Constitución a la protección

tudios: la política en Chile, 2, XXX (2011), 109-148. Otros autores hablan de un "constitucionalismo formal" en las Fuerzas Armadas, que en momentos de crisis o lucha entre los poderes del Estado las lleva a actuar cuando se piensan como "el único poder capaz de mantener el orden republicano". $\mathrm{Al}$ respecto ver Augusto Varas, Felipe Agüero y Fernando Bustamante, Chile, Democracia, Fuerzas Armadas (Santiago: FLACSO, 1980), 74-79 y 234.

42 Se puede seguir este proceso en Diego Barros Arana, Historia Jeneral de Chile (Santiago: Josefina M. de Palacios, Editora, 1897), t. XV, 350-379. Ver "Encargar el mando supremo de la República al Presidente del Senado", firmada por Francisco Antonio Pinto, Santiago, 2 de noviembre de 1829, en Sesiones de los Cuerpos Legislativos, Tomo XIX, Anexo No 197.

43 Armando Cartes, Concepción contra Chile.

44 La reacción en el sur en Diego Barros Arana, Historia Jeneral de Chile, 387-394. 
del ejército". El documento aparecía firmado, entre otros, por Joaquín Prieto, Manuel Bulnes, José Antonio Villagrán y Justo Arteaga ${ }^{45}$.

Finalmente, es preciso considerar una cuestión relevante: el quiebre que se produjo a partir de estas elecciones, en la práctica, cerró la primera fase de formación republicana, terminó con los ensayos constitucionales y abrió paso a una nueva etapa histórica. En 1829 el general Joaquín Prieto se levantó contra el gobierno, fijó su posición en una proclama, con argumentos que evidenciaban una clara deliberación política y constitucional:
"Gloriaos de pertenecer a pueblos libres, en que no sois máquinas mo- vidas por la voluntad ciega del despotismo. Sois ciudadanos armados que gozando los mismos derechos que vuestros pacíficos hermanos, tenéis el propio deber que ellos de dar vuestra libertad en la defensa de la ley, a que consagráis esta campaña. Los pueblos están pronunciados. Está contestado el horroroso hecho de haberse infringido la constitu- ción aun por los mismos a quienes se dirigió tan funesto obsequio. En el Estado de Chile no hay más liberticidas que una mayoría corrompida de vuestros mismos representantes en las cámaras" ${ }^{\text {"46 }}$.

En la misma línea se expresaba El Sufragante, que rechazaba el proceder del Congreso, afirmando que "los pueblos deben negarle obediencia", ya que la mayoría de sus miembros había preferido sus intereses personales sobre los de la nación, mostrando "el desprecio con que consideran la constitución", delito por el cual debían ser acusados y castigados ${ }^{47}$. La Bandera Tricolor, tiempo después, explicaría que la nueva Constitución, en la época de las elecciones, los mismos que estaban encargados de ejecutarla y hacerla ejecutar, la infringieron; el cargo de vicepresidente "fue conferido arbitrariamente" a un candidato con número inferior de sufragios, por lo cual su nominación "fue ilegal". Como resultado, decía el medio, los pueblos del sur reasumieron sus

\footnotetext{
45 “Apoyo del Ejército del Sur a la Asamblea de Concepción", 9 de octubre de 1829, en Sesiones de los Cuerpos Legislativos, Tomo XIX, Anexo No. 144, p. 153.

46 Joaquín Prieto, "Proclama del General Prieto a sus soldados" (Hoja suelta, Chillán, sde, 24 de octubre de 1829).

47 El Sufragante, No. 6 (22/9/1829).
} 
facultades ${ }^{48}$. Con ello, defendían la postura que legitimaba el levantamiento militar, precisamente porque se realizaba contra quienes habían vulnerado la carta fundamental.

La respuesta del gobierno no tardó en esperar:

"El Congreso General, atendiendo las críticas circunstancias que rodean el país, no ha podido menos que acordar se invite a S. E. para que, sin pérdida de instantes, compela al señor Capitán General don Ramón Freire a que tome el mando de las fuerzas de la República. Esta medida, a juicio del Congreso, hará cambiar el horrible aspecto que presenta la nación y será tanto más fructuosa cuanto con más celeridad se ejecute" $"$.

Había comenzado la guerra civil. Sin entrar en detalles, se puede afirmar que parte importante del Ejército de la capital se mantuvo leal a la administración liberal, incluso se le ha llamado ejército liberal, lo que ilustraría sus preferencias políticas ${ }^{50}$. Mientras tanto, el Ejército del Sur que dirigía Prieto se levantó contra ese mismo gobierno. Sería ilusorio suponer explicaciones monocausales a un proceso que fue muy complejo en su génesis y que tenía claramente antecedentes en los años anteriores, marcados por numerosos levantamientos militares, motivados por diversas razones.

En diciembre del mismo año una proclama de los autodenominados "constitucionales" expresaba que el "ex General Prieto desde el primer día de su llegada se ha prestado sordo a la imperiosa voz de la razón y de la ley" ${ }^{2}$. La defensa del líder militar de la revolución -en artículo publicado en El Araucano- expresaba que el general se había puesto al frente "del extraordinario y grandioso movimiento que ocasionaron en toda la República las infracciones de la carta constitucional". El periódico acu-

48 La Bandera Tricolor, Serena, "Asamblea de Coquimbo" (7/4/1831) y "Continuación. ¿Cuál es el origen de la instabilidad de las instituciones en Chile, y cómo podrá afianzarse su estabilidad" $(10 / 10 / 1831)$.

25449 "El Vicepresidente de la Cámara de Senadores a S. E. el Jefe Supremo de la República", Santiago, 2 de noviembre de 1829, en Sesiones de los Cuerpos Legislativos, Tomo XIX, Anexo N² 200, 191.

50 Federico Errázuriz, Chile bajo el imperio de la Constitución de 1828, 340.

51 Los Constitucionales (1829), "Chilenos" (Santiago, Imprenta Republicana). 
saba a las autoridades por diversas violaciones a la constitución, mientras que los pueblos habían abrazado con entusiasmo el levantamiento:
"Esta conducta dio a conocer que semejantes hombres eran capaces de fijar en Chile el orden que todos desean, pues siendo los primeros que debían dar ejemplos de respeto y veneración a la ley, no solamente no vengaron las ofensas que se le habían hecho, sino que las autorizaren con repetición de otras, aún más graves por el carácter que ellos inves- tían. Con estas violaciones echaron por tierra ese código que los había instituido y rompieron los vínculos que ligaban a los pueblos con todos los magistrados y funcionarios" ${ }^{52}$.

Ambas posturas reflejaban una clara contradicción de puntos de vista en un momento culminante de la historia de Chile. Mientras desde el gobierno calificaban de "ex" uniformado a quien se había levantado contra la administración, los sublevados enfatizaban que era el propio gobierno el que había “infringido la Constitución”, razón suficiente para encabezar un levantamiento contra una administración que -sostenían- había devenido en ilegítima.

Por el contrario, la administración llamó a la lealtad de los militares, y se encargó al Capitán General Ramón Freire el mando de las fuerzas de la república:

"El Congreso Nacional, atendiendo a las críticas circunstancias que rodean el país, no ha podido menos que acordar se invite a S. E. para que, sin pérdida de instantes, compela al señor Capitán General don Ramón Freire a que tome el mando de las fuerzas de la República. Esta medida, a juicio del Congreso, hará cambiar el horrible aspecto que presenta la nación y será tanto más fructuosa cuanto con más celeridad se ejecute" ${ }^{93}$.

Con esto quedaban fijadas las dos posturas principales que se enfrentaron en la guerra civil, en la que cada grupo estaba convencido de tener razones suficientes para obrar de la forma que habían decidido, aunque

52 “General Prieto", en El Araucano, № 8 (6/11/1830), 3-4.

53 "Encargar al Capitán General don Ramón Freire el mando de las fuerzas de la República", Santiago 2 de noviembre de 1829. Sesiones de los Cuerpos Legislativos, Tomo XVIII, 191. Anexo Nº 200. 
ello significara una contradicción profunda y un enfrentamiento armado que traería muerte y destrucción al país. Adicionalmente, se trataba de un choque que enfrentaba, de manera dramática y fratricida, a personas que habían luchado juntos en la independencia.

Esta historia tuvo contradicciones dolorosas y cambios históricos. Los "sublevados" contra el gobierno vencieron a los "sublevados" contra la Constitución, si observamos la forma como se definían los grupos en pugna. El resultado fue la inauguración de una nueva administración en 1831, liderada por un militar, precisamente quien había encabezado la rebelión de 1829, el general Joaquín Prieto. La situación tuvo una segunda consecuencia a pocos años plazo: el nuevo gobierno de Prieto, del sector conservador de la sociedad chilena y con una fuerte influencia del ministro Diego Portales decidió crear una nueva constitución tras una propuesta del Cabildo de Santiago, en febrero de 1831-, con lo cual la rebelión militar y el nuevo gobierno dirigido por un uniformado adquiría un carácter constituyente.

Así nació la Constitución de 1833, fruto directo de todo el proceso iniciado en la rebelión de 1829, que sería un resultado jurídico destinado a durar muchas décadas. En lo formal, se presentó como un proyecto de reforma a la Constitución de 1828, y en la práctica mantenía mucho de su contenido, aunque la nueva carta fortaleció en un principio la autoridad del Presidente de la República. Podría decirse que ella había nacido, paradojalmente, de un ejercicio específico de "desobediencia" y "deliberación" militar. No está de más recordar que esta nueva carta establecía expresamente el mismo principio constitucional respecto de las instituciones militares: "La fuerza pública es esencialmente obediente. Ningún cuerpo armado puede deliberar" ${ }^{54}$. Luego agregaba: "Toda resolución que acordare el Presidente de la República, el Senado, o la Cámara de Diputados a presencia o requisición de un ejército, de un general a la frente de fuerza armada, o de alguna reunión de pueblo, que

54 Constitución Política de la República de Chile, Jurada y promulgada el 25 de mayo de 1833 (Santiago, Imprenta de la Opinión, 1833), Artículo 157. 
ya sea con armas o sin ellas desobedeciese a las autoridades, es nula de derecho y no puede producir efecto alguno" 55 .

En este sentido, había una continuidad doctrinal, y también un deseo de detener las continuas asonadas y motines militares que caracterizaron la década de 1820 y que, habitualmente, terminaban sin castigos. La Constitución de 1833 no solo reivindicó el principio de obediencia y no deliberación, sino que también precisaba y complementaba sus consecuencias.

El tema tiene una relevancia historiográfica mayor, si consideramos que la omisión del fenómeno de la deliberación política de los militares ha dificultado la comprensión histórica de un fenómeno de gran relevancia como la guerra civil de 1829 y 1830, que requeriría una investigación más extensa y compleja. El enfrentamiento entre "pipiolos" y "pelucones" sólo se revisa levemente en las investigaciones especializadas, y su análisis más detallado aparece presente en las historias generales de Chile, pero sin una consideración mayor hacia el tema de la deliberación militar en política y la comprensión específica del principio de obediencia constitucional del ejército.

\section{LOS MILITARES Y LA CRISIS CONSTITUCIONAL DE 1829-1830. ¿OBEDECER O DELIBERAR?}

La Constitución de 1828 y la guerra civil del año siguiente han merecido diferentes estudios y análisis. No ha ocurrido igual cosa con el factor militar, no sólo en los hechos, sino también en las definiciones constitucionales que motivaban la acción de los diversos líderes castrenses y sus subordinados. Una revisión en esta línea permite conocer los hechos y las motivaciones, pero también sus fundamentos doctrinarios y jurídicos, y su eventual proyección en la historia de Chile. En otras palabras, contribuye a comprender las razones que llevaron a algunos uniformados a defender al gobierno de turno y condujeron a otros a levantarse contra él. A diferencia de las incursiones militares previas muchas veces motivadas por problemas económicos y por no pago de

55 Constitución Política de la República de Chile (1833), Artículo 158. 
sueldos-, en 1829 la situación fue más compleja y tuvo una discusión constitucional más densa ${ }^{56}$.

Por otra parte, resulta interesante la condescendencia de las autoridades hacia los amotinados en diversas ocasiones. En septiembre de 1828 una ley estableció: "Queda desde esta fecha sancionada una ley de olvido, la más extensa y general para todos los comprendidos en movimientos, causas de revolución y partidos; de hecho en virtud solo de esta ley" 57 . A comienzos de 1829 hubo un indulto que estableció que "todo hombre prófugo por causa de sedición y motín puede volver libremente a sus hogares y al goce de todas las garantías sociales", lo que implicaban rendir fianza de buen comportamiento ante las autoridades provinciales. El gobierno se proclamaba solícito "por el alivio de los desgraciados" y esperaba que todos respetaran la Constitución y las leyes ${ }^{58}$.

¿Qué debía ocurrir en esta nueva ocasión? ¿Cómo enfrentar un nuevo levantamiento militar contra el gobierno de turno?

Un primer aspecto que no es posible eludir, se refiere a las interpretaciones constitucionales vigentes en ese momento en Chile. Ambos sectores, en sus soportes políticos y militares, sostenían conceptualmente principio de obediencia y no deliberación militar, que era la doctrina del Ejército establecida constitucionalmente. La diferencia se producía en la interpretación. Por el lado del Ejército del gobierno, ellos pensaron que lo único que cabía en las circunstancias que vivía Chile era obedecer al gobierno sin otra consideración.

Así resumió su posición el coronel Guillermo Tupper, quien defendió la posición oficial, contra los sublevados: "Sobre todo considero que ningún Gobierno libre o Estado libre bien constituido puede existir una hora si los militares estuviesen autorizados para arrojar la espada en la

56 En cualquier caso, antes de 1829 las rebeliones también tuvieron elementos doctrinarios presentes, como el carácter más liberal o federalista de las manifestaciones.

57 "Ley de Olvido", Anexo N³97, en Sesiones de los Cuerpos Legislativos, Tomo XVI, p. 333.

58 "Indulto", 17 de febrero de 1829, en boletín de las leyes y las órdenes y decretos del gobierno, Libro Tercero (Santiago, Imprenta de la Independencia, 1839, Segunda edición) 81. 
balanza y decidir puntos de legislación por la fuerza de las armas, como es ahora el caso general de Sudamérica" ${ }^{29}$.

Refiriéndose a la situación específica que se presentaba en Chile en 1829, el militar de origen británico expresaba estar "convencido de que el asunto en controversia no era uno de los llamados a dirimirse por la intervención militar", con lo cual reconocía que otros casos sí podrían solucionarse de esa manera. En una de las primeras reuniones que tuvo con Freire para organizar la defensa de las autoridades gubernativas, el propio coronel Tupper expresó que "servía a un gobierno justo y legal, creía indigno de su profesión el dar lecciones a los que la República había elevado al supremo mando, siendo su deber sólo obedecer las órdenes que se le dieran" ${ }^{\prime 60}$.

La oposición, por su parte, consideraba que el pacto constitucional había sido roto por las propias autoridades. "Está contestado el horroroso hecho de haberse infringido la constitución", había expresado el general Prieto en una proclama decisiva, ilustrando la ruptura del pacto político. En la misma línea se pronunciaban algunos de los líderes civiles de la oposición de 1829, José Tomás Ovalle, Isidoro Errázuriz y José María de Guzmán: "Ha triunfado, pues, la causa de los pueblos, de la libertad y la Constitución hollada por los que con tanto descaro se llamaban constitucionales; pero ese triunfo nos ha impuesto obligaciones de un carácter el más sagrado. Los infractores rompieron los lazos que unían la República, y por una consecuencia precisa de sus infracciones, la Constitución ha suspendido sus efectos y carece de un gobierno general" $" 61$.

El Sufragante destacó un argumento referido exclusivamente a los militares, que permite explicar la posición de los sectores opositores que encabezaron el levantamiento de 1829, que comprendían como "la lucha que emprendieron los pueblos contra los infractores de la Consti-

59 Guillermo Tupper, Memorias del Coronel Tupper (Buenos Aires: Editorial Francisco de Aguirre, 1972), 56.

60 Federico Errázuriz, Chile bajo el imperio de la Constitución de 1828, 118-119.

61 "Circular a los intendentes de las provincias", 7 de enero de 1830, en Sesiones de los Cuerpos Legislativos, Tomo XVIII, 206-208. 
tución”, por lo cual "subyugado el pueblo por una parte del ejército, le fue preciso llamar a la otra en su auxilio" 62 .

Otro documento enfatizaba que la acción del ejército del sur había sido causada por la opresión de las fuerzas que "aparentando a la vez no mezclarse en cuestiones populares, a la vez obedecer y no obedecer a la autoridad y siempre llevando adelante cuestiones personales, mantuvieron a esta ciudad en la situación más amarga, que amenazó su destrucción". Todo eso concluyó en una lucha en la que corrió sangre de hermanos, la que siempre clamará "contra los que, no queriendo dejar a los pueblos en libertad y sujetarse a sus decisiones, fueron la causa de que se vertiera sin un motivo justo entre los soldados de la Independencia"63.

\section{VENCEDORES Y VENCIDOS. REVISIONES Y EXPLICACIONES DE LA DOCTRINA DEL EJÉRCITO}

La guerra civil terminó con la victoria del Ejército del Sur y del general Joaquín Prieto, que consolidaron el resultado después de la decisiva batalla de Lircay.

Como consecuencia, después de un gobierno provisorio y de la breve administración posterior al conflicto, que dirigió José Tomás Ovalle en una primera etapa y luego Fernando Errázuriz, fue un llamado a elecciones y la inauguración de una nueva administración. A partir de 1831 gobernaría el país un militar que había liderado la revolución de 1829, el general Joaquín Prieto, con gran influencia de Diego Portales. La nueva administración decidió crear una nueva constitución, con lo cual la rebelión militar y el nuevo gobierno dirigido por un uniformado adquiría un carácter constituyente.

En cuanto a los resultados, el nuevo gobierno avanzaba en sus deseos de realizar cambios en Chile y lo hacía con decisión, mientras la nueva

63 "Mensaje en que la Junta encargada del Gobierno de la provincia felicita al Congreso y le expone cuál es la situación política", 12 de febrero de 1830, en Sesiones de los Cuerpos Legislativos, Tomo XVIII, 216-218. 
oposición vivía una situación exactamente a la inversa, y comenzaba a padecer de los dolores de la derrota. El 21 de abril de 1830 el general Prieto comunicó que las personas que fueron hechas prisioneras tras la batalla de Lircay se encontraban en el cabildo de la ciudad de Talca, con la excepción de aquellos que habían sido enviados al hospital, a consecuencia de sus heridas ${ }^{64}$. Con esa información, el Congreso de Plenipotenciarios acordó autorizar al Presidente de la República para que destinaran, dentro o fuera del país, a todos los prisioneros que habían servido al general Freire, como una medida para garantizar la tranquilidad pública ${ }^{65}$.

En esa línea, una vez que fue detenido Ramón Freire, lo condujeron a Valparaíso, donde debía elegir un lugar de residencia "fuera del territorio de la República". Ovalle y Portales explicaban que esa era una medida necesaria "para la completa seguridad del país" y para "acabar con el último apoyo de los anarquistas" ${ }^{66}$. Finalmente, Freire partió a Perú.

Por otro lado, comenzaron los premios a los vencedores. Una propuesta de José Tomás Ovalle y Diego Portales pedía al Congreso promover el ascenso de un grupo de militares por "los importantes servicios que han prestado a la Nación" durante el alzamiento contra el régimen liberal. No está de más señalar que la propuesta fue acogida a cabalidad ${ }^{67}$. Si el gobierno anterior había condenado a estos uniformados por rebeldes, ahora eran premiados por la misma razón, porque se estimaba

64 "De un oficio con que S. E. el Vicepresidente de la República acompaña una nota del General en Jefe don Joaquín Prieto, quien consulta sobre el destino que se debe dar a los prisioneros tomados en Lircay", en Sesiones de los Cuerpos Legislativos, Tomo XVIII, Documento No. 426, 324.

"Autorizar al Gobierno para destinar dentro o fuera de la República a los prisioneros de Lircay y a todos los individuos cuya traslación juzgue él necesaria al orden público", Documento $\mathrm{N}^{\circ} 427$, en Sesiones de los Cuerpos Legislativos, Tomo XVIII, 324.

66 "De otro oficio en que el mismo Magistrado comunica que, aprehendido el 26 de los corrientes don Ramón Freire, le ha hecho salir camino de Valparaíso convenientemente custodiado para extrañarle de la República”, 27 de mayo de 1830, en Sesiones de los Cuerpos Legislativos, Tomo XVIII, Documento No. 460, 344-345.

67 "De un oficio en que S. E. el Vicepresidente de la República propone el ascenso de los jefes militares cuya nómina acompaña", 19 de mayo de 1830, y "Autorizar al Poder Ejecutivo para conceder ascensos a los jefes militares que indica la nómina”, 22 de mayo de 1830, en Sesiones de los Cuerpos Legislativos, Tomo XVIII, 331-332. 
que era un levantamiento contra autoridades que habían llegado a ser ilegítimas.

Un momento decisivo para conocer e interpretar las razones de los militares que habían permanecido junto a la administración bajo la Constitución de 1828 se produjo a comienzos de marzo de 1830, cuando fueron convocados al Congreso de Plenipotenciarios algunos de esos uniformados. En esa ocasión se les consultó expresamente sobre su posición ante el nuevo gobierno, nacido de la sublevación del Ejército del Sur. La pregunta era formulada de la siguiente manera: "¿Reconocen y obedecen al Congreso Nacional de Plenipotenciarios o no?” Las respuestas fueron de una notable unanimidad; en realidad apenas hubo una sola excepción: "El coronel Picarte: No reconozco al Congreso, como militar. El general Las Heras: habiendo cesado la autoridad constitucional de quien obtuve mi despacho, creo que ha cesado mi carácter y para volver a entrar en nuevo ejercicio de él, creo que es obra de un nuevo pacto al cual no estoy dispuesto. El general Borgoño: habiendo cesado el régimen constitucional, he dejado de ser un funcionario público. El general Urquiso: reproduzco lo que dijo el general Las Heras. El general Lastra: habiendo cesado el régimen constitucional no me creo un funcionario público hasta que reviva otra vez la marcha de la Constitución. El sargento mayor Blanco: reproduzco lo que dijo el general Lastra. El coronel Cáceres: como militar, creo haber cumplido en el contexto que di al señor general Prieto, comandante de armas de Santiago, entonces; y hoy, llamado por el Congreso de Plenipotenciarios, reconozco su autoridad. Y se retiraron, reconociendo sólo el último al Congreso" $"$.

En síntesis, estos uniformados reconocían al gobierno previo, señalaban que les correspondía obedecerlo de acuerdo a las normas entonces vigentes, expresaban no reconocer a la nueva administración nacida del resultado de la guerra civil, acusando la no existencia de régimen constitucional. Solo el coronel Cáceres reconoció la autoridad del nuevo gobierno.

68 Congreso de Plenipotenciarios, 4 de marzo de 1830, en Sesiones de los Cuerpos Legislativos, Tomo XVIII, 250. 
Por su parte, la administración tenía claro que todos los militares disidentes debían pasar a retiro, que no tenía sentido alguno -y por el contrario, era muy peligroso- que siguieran en el Ejército:
"El Gobierno faltaría ya a sus más esenciales obligaciones, si después de una conducta tan criminal y que ha sacrificado tantas víctimas, no declarase ante la Nación toda que don Ramón Freire y los militares que le siguen, son los más encarnizados enemigos de la Patria, y si al mismo tiempo que usa de sus armas para contener su osadía, no los excluye de la lista del Ejército nacional, a que no deben pertenecer sin deshonrarlo con sus nombres".

Como consecuencia de esta evaluación de la situación, fueron dados de baja el propio Freire, además del jefe, los oficiales y tropa que estaban bajo sus órdenes. La única excepción eran aquellos soldados que depusieran voluntariamente las armas y se pasaran a las filas del "ejército nacional", nombre con el cual se denominaban los vencedores ${ }^{69}$. El decreto, firmado por Ovalle y por Portales, quedaba a cargo del ministro de Guerra para su cumplimiento.

La lista de sancionados era mucho más larga, e incluía a los mandos más altos del ejército ${ }^{70}$. Entre ellos se puede mencionar -además del Capitán General Ramón Freire-, a los generales José Manuel Borgoño, Francisco Calderón, Juan Gregorio de las Heras, Francisco de la Lastra y Francisco Antonio Pinto, a los coroneles Francisco Formas, José Rondizzoni y Benjamín Viel, y una larga nómina de sargentos, tenientes coroneles y capitanes, entre otros.

La dureza de estas medidas se inscribe en la decisión del ministro Diego Portales de combatir la sedición y la posibilidad de nuevas asonadas militares, es decir, para garantizar la seguridad interior ${ }^{71}$. En palabras de

69 "Bajas militares", 17 de abril de 1830, Documento No. 624, Sesiones de los Cuerpos Legislativos, Tomo XVIII, 429-430.

70 La lista en Benjamín Vicuña Mackenna, Don Diego Portales (Santiago: Universidad de Chile, 1937), 653-655.

71 Gonzalo Rojas, "Portales y la seguridad interior del Estado", en Chile en épocas de crisis. Estudios sobre partidos, ideologías y libertades, Gonzalo Rojas (Santiago: Historia Chilena, 2015). Ver también Sergio Vergara, "Portales y el Ejército", en Portales. El hombre y su obra. La consolidación del 
Encina, era "incompatible su presencia en las filas [del ejército] con el nuevo concepto de la obediencia pasiva a las autoridades constituidas". A esta medida se sumó la regularización de los pagos en el ejército, con lo cual se extirpaba otro foco de generación de motines ${ }^{72}$. Era otro de los signos del cambio de época.

\section{El DEFENSOR DE LOS VENCIDOS}

Los vencidos, como suele ocurrir, quedaron en pésimas condiciones económicas y sociales, aunque contaron con una nueva defensa doctrinal que pretendía ayudarlos en las difíciles circunstancias y fijar para la historia una forma de ver el problema. Para ello recibieron la solidaridad de un periódico titulado, de manera elocuente, El Defensor de los Militares Denominados Constitucionales ${ }^{73}$.

El Defensor comenzó a circular el 26 de junio de 1830 y tuvo 20 ediciones hasta su desaparición el 2 de octubre del mismo año. El promotor y redactor del medio era el siempre activo liberal español José Joaquín de Mora, quien también había participado en la elaboración de la Constitución de 1828.

Ya en el primer número el periódico fijó en dos líneas un elemento fundamental de su doctrina: "en ningún caso la fuerza armada debe ni puede intervenir en las cuestiones de derecho público" ${ }^{\text {"74 }}$. Entre sus argumentos destacaba que así lo había establecido la ley fundamental, que había sido sancionada legítimamente. La regla básica de la fuerza militar era "la estricta obediencia al Poder Ejecutivo", por lo cual en "ningún caso por razón alguna... le dio facultad para deliberar por sí en materias del derecho civil" "75. En síntesis, "los militares no pudieron ni debieron obrar de otro modo. No pudieron, porque la ley les ordenaba obedecer a su superior sin replicar y este les mandó hacer el uso de las armas que

gobierno civil, Bernardino Bravo Lira (Santiago: Editorial Jurídica-Andrés Bello, 1988).

72 Francisco Antonio Encina, Historia de Chile (Santiago: Editorial Nascimento, Segunda Edición, 1962), Tomo X, 548-549.

26473 Diego Barros Arana, Historia Jeneral de Chile (Santiago: Imprenta Cervantes, 1902), Tomo XVI, 5-13.

74 El Defensor de los Militares Denominados Constitucionales, No. $1(12 / 7 / 1830)$.

75 El Defensor de los Militares Denominados Constitucionales, No. $1(12 / 7 / 1830)$. 
han hecho. No debieron, porque habían jurado esa obediencia ciega bajo la pena de perder honor, empleo y vida" ${ }^{\text {"76 }}$.

El Defensor planteaba entonces la definición más radical, la doctrina de la "obediencia ciega". Es decir, bajo ninguna circunstancia los uniformados pueden poner en tela de juicio una orden emanada del Poder Ejecutivo. Contrastando la postura que hablaba de los "ciudadanos armados" -aquellos que debían respetar la opinión pública"-, el periódico prefería destacar que "todas las formas de gobierno conocidas convienen en el principio, de que la fuerza militar esté estrictamente sometida al poder civil'"77.

Una posición distinta implicaría una verdadera locura por parte del legislador y de los gobiernos de turno: "Si hubiese una ley que diese al poder militar el de deliberar, pero que decimos ley, si algún hombre se atreviese a proponerla, este pasaría por un loco, y aquella, en caso de dictarse, por uno de los más despreciables absurdos, por una producción de la estupidez y barbarie" 78 . Por lo mismo, no hay delito más grande que "la falta de subordinación", pues siempre se debe estricta obediencia a las autoridades superiores, y debe ser "inexorablemente castigado" cualquier atentado contra estas obligaciones ${ }^{79}$. Esto resulta doblemente interesante, porque no sólo era una defensa hacia los derrotados en la guerra civil, sino también un ataque y petición de castigo contra quienes se habían sublevado y obtenido la victoria en los campos de batalla. Así lo expresaba en una larga e interesante reflexión, reclamando que el ejército del sur y su general no tenían derecho legal alguno:

"ese auxilio a mano armada procedía de un origen reprobado por las leyes, tanto militares como civiles, y era destructor de los principios inconcusos que dejamos sentados: en su virtud, la fuerza militar, que guarnecía a Santiago, creyó, fundándose en el obedecimiento que debía a esas leyes y respeto a los principios generales aducidos, que nadie era permitido faltar a sus juramentos, deliberar por sí, ni erigirse en poder

76 El Defensor de los Militares Denominados Constitucionales, No. $1(12 / 7 / 1830)$.

77 El Defensor de los Militares Denominados Constitucionales, No. $1(12 / 7 / 1830)$.

78 El Defensor de los Militares Denominados Constitucionales, No. 2 (17/7/1830).

79 El Defensor de los Militares Denominados Constitucionales, No. $1(12 / 7 / 1830)$. 
nacional; y si el general del ejército del sur [Prieto] había hallado ser justo obedecer a un cuerpo municipal creado por la Constitución, y que según todos decían entonces, se había excedido de las atribuciones que ésta le señaló, los jefes de los cuerpos, que guarnecían a Santiago, con más justa razón obedecieron a las autoridades nacionales, que esa Constitución les había señalado y mandado obedecer sin réplicas" ${ }^{\$ 0}$.

Además de la explicación del principio institucional de la fuerza armada, El Defensor argumentaba contra los riesgos de la dictadura y del gobierno militar. Sólo si jura obediencia y responde con honor y fidelidad, se elimina el peligro de que el uniformado "llegue a hacerse el opresor de su Patria, el amo de sus conciudadanos y la clase más funesta y ominosa al Estado" $"$.

Si algunos militares, contra esta doctrina, decidían desobedecer, deliberar y asumían posiciones de gobierno, entonces "considérese establecido el gobierno militar". ${ }^{82}$ Con ello se ha llegado al despotismo militar "el más insufrible en sentir de la mayor parte de los políticos, y la forma más monstruosa de gobierno conocido" 83 .

Esa era, precisamente, la situación a la que había ingresado Chile después de Lircay, a juicio de los vencidos, que no sólo habían sufrido la derrota sino también sus consecuencias: el exilio, la cárcel, la expulsión del ejército y las persecuciones. Eso llevó al Defensor a resumir claramente que "los militares han debido ser amparados como ciudadanos en sus empleos y sueldos", precisando que los castigos debían haberse suspendido mientras duraban los juicios contra ellos ${ }^{84}$. Y agregaba en otra ocasión: "Para condenar a estos militares a la pena de perder sus empleos, y considerarlos en clase de delincuentes, preciso ha sido juzgarlos conforme a las L.L., formales cargos e interrogarlos oyendo sus descargos y defensas. Ellos, la nación y las L.L. habrían quedado satis-

80 El Defensor de los Militares Denominados Constitucionales, No. 3 (24/7/1830).

81 El Defensor de los Militares Denominados Constitucionales, No. $1(12 / 7 / 1830)$.

82 El Defensor de los Militares Denominados Constitucionales, No. $2(17 / 7 / 1830)$.

83 El Defensor de los Militares Denominados Constitucionales, No. $2(17 / 7 / 1830)$.

84 El Defensor de los Militares Denominados Constitucionales, No. 11 (4/9/1830). 
fechos, ya fuesen condenados, ya absueltos; y si lo han injustamente, los juzgadores cargarían sobre sí una infinita responsabilidad" 85 .

El Defensor proclamaba que "todas las formas de gobierno conocidas convienen en el principio, de que la fuerza militar esté estrictamente sometida al poder civil", agregando con determinación: "La falta de subordinación, que es la estricta obediencia a las autoridades superiores, y de fidelidad a los juramentos que han prestado, son el delito más enorme, y más inexorablemente castigado que puede cometerse en esa clase" 86 .

Por otro lado, en relación a los uniformados que no acataban el principio de obediencia pasiva, la condena era lapidaria, contra dicha acción y contra sus consecuencias. Por ello, proclamaba que el militar "jura obediencia sin réplica, honor y fidelidad, y desprecia la muerte y todos los peligros por guardar estos deberes". De lo contrario el militar podría llegar a ser "el opresor de su Patria, el amo de sus conciudadanos y la clase más funesta y ominosa al Estado" $"$.

El tema de fondo era que, en su acción militar, habían obrado de acuerdo a las leyes vigentes, a juicio del periódico de Mora: "Cuando hubiesen sido un crimen haber cumplido con su deber estrictamente ¿cuándo habrían inocentes, principalmente, de los subalternos? ¿Cuántos habrían obrado sin el menor conocimiento de que incurrían en delito? ¿Cuántos en fin habrían sido arrastrados sin voluntad?" 88 El asunto es que "el militar no puede dejar de obedecer al superior que la ley le da: existiese o no en toda su fuerza el tratado de Ochagavía, el único deber de los que estaban a las órdenes del general Freire era obedecer a este jefe sobre quien recayó la responsabilidad" 89 .

En cuanto a la actitud que debían tener los militares vencidos ante el nuevo régimen establecido después de Lircay, El Defensor se hacía una

85 El Defensor de los Militares Denominados Constitucionales, No. 7 (10/8/1830).

86 El Defensor de los Militares Denominados Constitucionales, No. $1(12 / 7 / 1830)$.

87 El Defensor de los Militares Denominados Constitucionales, No. $1(12 / 7 / 1830)$.

88 El Defensor de los Militares Denominados Constitucionales, No. $7(10 / 8 / 1830)$.

89 El Defensor de los Militares Denominados Constitucionales, No. 4 (31/7/1830). 
pregunta crucial a fines de agosto de 1830: “¿Habrán delinquido los oficiales dados de baja, por no haber reconocido a las autoridades nuevamente creadas?" ${ }^{\circ}$ Esto planteaba un problema fundamental, ya no solo sobre la comprensión del principio de obediencia y no deliberación en el pasado, sino frente a una cuestión de hecho, como era el establecimiento de un nuevo gobierno, vencedor en la guerra civil.

Al respecto, el periódico se preguntaba, poniendo en duda la legitimidad del orden surgido del conflicto: "¿Un gobierno que obra abiertamente contra las bases de nuestra organización social, y que echa por tierra su Constitución, diciendo que trabaja por establecerla, su imperio merecerá la confianza pública, cuando atropella sus más preciosas prerrogativas?" 91 .

Por lo mismo, se preguntaba retóricamente, poniendo en duda las bases del nuevo gobierno:

“Unas autoridades que no han podido ser legales bajo de ningún aspecto, como lo ha demostrado el Defensor en su número anterior, y que no tienen más fundamento que la existencia de hecho por los contrastes desgraciados que hemos sufrido, tendrán facultad para obrar abiertamente contra la voluntad de la Nación, tan expresamente pronunciada en su ley fundamental por cuyo restablecimiento se han sacrificado tantas garantías?" 92 .

Sin embargo, ya era demasiado tarde. El periódico El Popular consideraba que El Defensor de los militares denominados constitucionales era "el folleto más despreciable que ha podido ocupar nuestras prensas"93. La victoria pelucona en la guerra civil había dado paso a un nuevo orden, que se consolidaría en el gobierno del general Joaquín Prieto en 1831 y con la reforma a la Constitución de 1828, publicada como Constitución de 1833. Y la interpretación de los vencedores era radicalmente distinta, reafirmando que la sublevación respondía a la voluntad 
popular, mientras el gobierno se había puesto previamente al margen de la ley. Así lo fundamentaba un artículo publicado en El Araucano a fines de 1830:

"No puede imputarse a rebelión esa desobediencia al gobierno general que se le atribuye, pues éste no existía ya, sino en la opinión de sus adictos, porque las infracciones de esa ley que le había dado el ser, lo hicieron cesar, y el general Prieto no veía más autoridad sobre sí, que la voluntad de los pueblos. Los que trataron de sojuzgarla, son los rebeldes; los que desoyeron su voz son los insubordinados; los que llevaron la resistencia hasta el extremo de hacer que los soldados Chilenos se matasen unos con otros, son los autores de los desastres de Chile"'94.

Por otra parte, como sostenía nuevamente El Popular, eran los ex militares a los cuales apoyaba El Defensor quienes habían faltado a su primer deber de obediencia a la Constitución infringida, con lo cual se convirtieron en "verdaderos desertores de la honrosa carrera a que pertenecían", faltando a sus juramentos y convirtiéndose en opresores de los pueblos. El texto concluía con una argumentación que utilizaron los vencedores de la guerra civil:

"Si la fuerza armada no debe mezclarse en las cuestiones civiles, es consecuencia necesaria que don Ramón Freire no pudo, bajo título alguno, entablar una guerra para reinstalar como decía las autoridades constitucionales que habían echado a tierra el voto público, por sus notorias infracciones; si no pudo hacerlo, ningún militar debió seguirle en semejante empresa" 95 .

Como resumía otro periódico, el general Freire no podía reinstalar un gobierno que había caducado "por haber infringido la Constitución"

Comenzaba otra historia y quedaban fijadas las diferentes interpretaciones sobre la obediencia y no deliberación de los militares.

94 “General Prieto", El Araucano, No. 8 (6/11/1830).

95 "Al Defensor de los militares denominados constitucionales", El Popular, No. 16 (17/7/1830). Cursivas en el original.

96 El Sufragante, No. $12(30 / 1 / 1830)$. 


\section{Conclusiones}

La década de 1820 resultó decisiva para la historia de Chile, tanto por los avances que representó como por las contradicciones que experimentó. Una visión actualizada y desapasionada de esos años nos permite alejarnos tanto de las descalificaciones absolutas sobre el periodo -habría sido una anarquía y un completo desastre- como de las fórmulas que a veces olvidan los retrocesos y las caídas del proceso, como si hubiera sido simplemente un aprendizaje político más. Las fuentes resultan claras en mostrar ambos lados de la cuestión y, por lo mismo, una visión más ecléctica contribuye a una mejor comprensión del proceso de construcción republicana.

Esto tiene un valor especial cuando nos asomamos al problema constitucional y al tema de la participación del Ejército en las actividades políticas del país. En un momento en que los países herederos de la monarquía hispánica adoptaban fórmulas caudillistas y no lograban estabilidad institucional, los militares pasaron a ser agentes de cambios gubernativos y de administración del país ${ }^{97}$. Lo mismo ocurrió en Chile, en lo que podríamos llamar un militarismo sui generis.

En primer lugar, es evidente que en las primeras décadas de desarrollo institucional republicano los militares desempeñaron distintas funciones públicas ajenas a las meramente profesionales. En concreto, ingresaron a la actividad política, gobernaron, integraron congresos y resolvieron conflictos en una u otra dirección.

En segundo término, varios de los militares que participaron en política llegaron al gobierno por la fuerza, pero con un final que podría aparecer como paradójico: también dejaron los cargos de gobierno para evitar conflictos mayores -tal fue el caso de O’Higgins a comienzos de 1823-, o porque había terminado su plazo constitucional para ocupar la Primera Magistratura, como ocurrió con Prieto en 1841 y con Bulnes diez años después.

97 Claudio Rolle, "Los militares como agentes de la revolución", en La Revolución Francesa y Chile, eds. Ricardo Krebs y Cristián Gazmuri (Santiago: Editorial Universitaria, 1990). 
Distintas constituciones establecieron claramente el principio que debía regir la función profesional de los militares, que se resumía en dos grandes ideas: la obediencia y la no deliberación. Con ello, prevenía que los uniformados desobedecieran a las autoridades legítimas, que se transformaran en órganos deliberantes, que decidieran por la fuerza el camino que debía adoptar Chile en materias gubernativas.

El asunto, sin embargo, tenía una dimensión compleja, habitualmente omitida en los análisis históricos, pero que deriva su fuerza no en la letra de la Constitución, sino que de la interpretación práctica de ella, como se manifestó especialmente en momentos de crisis política. Cuando hay interpretaciones contradictorias sobre un determinado aspecto constitucional o las autoridades políticas reclaman el apoyo de los uniformados: ¿A qué o a quién debe obedecer el militar, para cumplir el precepto que señala que la fuerza armada es "obediente"? El asunto tiene dos caras, ambas relevantes e integradas.

En primer lugar, los uniformados -también las demás instituciones nacionales- deben obedecer a la Constitución del país. Como establecía la carta de 1828, ella era "el principal elemento de nuestra existencia política", nacida de la razón más que del poder: "Cesaron para nosotros los tiempos en que la suerte nos condenaba a la ciega obediencia de una autoridad sin límites". Luego, la carta señalaba que las normas jurídicas "con mucho más rigor tratan a los depositarios de la autoridad. Ellas les señalan un espacio limitado, les exigen un respeto inviolable a la voluntad de la Nación y a los derechos de los individuos". El prólogo de la Constitución contemplaba, expresamente, el inmenso valor de la nueva organización política: "Observemos no sólo con exactitud y con fidelidad, sino con celo y entusiasmo la Constitución que de sus manos hemos recibido. Esta observancia es lo único que puede salvarnos"

En segundo lugar, los uniformados debían una obediencia específica al gobierno de turno, al Presidente de la República y a sus superiores jerárquicos dentro del mismo ejército. No lo establecía formalmente

98 Constitución política de la República (1828). Ver carta de Francisco Antonio Pinto, Vicepresidente de la República, a la nación. 
la Constitución de 1828 -como sí lo había hecho en 1823 y lo haría en 1833-, pero la doctrina de los publicistas y los periódicos era muy clara en este sentido.

La guerra civil de 1829 marcó, en buena medida, un cambio crucial en la historia de Chile. Por una parte, resulta claro que el ejército se dividió con ocasión de las elecciones de Presidente de la República y de Vicepresidente, generando una situación muy difícil para la administración del país. En medio del conflicto se produjo una doble y contradictoria deliberación militar, tanto de los uniformados que apoyaron al gobierno como de aquellos que se rebelaron contra él.

En el primer caso, existió una adhesión tanto al principio de obediencia y no deliberación militar, como al gobierno en ejercicio. Como dijeron muchos soldados en esa ocasión, no les parecía que Chile viviera el caso en el cual el ejército debía inclinar la balanza, por lo cual permanecían en sus puestos de una manera pasiva, determinada y obediente. El Ejército del Sur, por su parte, que se levantó en armas contra la administración, tuvo la postura inversa: como el gobierno se había puesto fuera de los marcos de la Constitución, ya no existía el deber de obedecerle, sino que correspondía seguir las normas constitucionales y las leyes del país, y no al gobierno que las violaba. Había cesado el pacto político que los unía.

El resultado de esa situación, en la práctica, fue una guerra civil que concluyó con el triunfo opositor. Todavía más: si en la década de 1820 algunas rebeliones habían culminado exitosamente, esas victorias duraban muy poco y rápidamente los militares volvían a sus cuarteles, eran sancionados y la situación quedaba en nada. Con la guerra civil de 18291830 la historia tomó un rumbo diferente: el gobierno de turno no sólo fue derrotado por la fuerza, sino que a la larga el líder de la insurrección, el general Joaquín Prieto, llegó a ser Presidente de la República en 1831 y gobernó hasta 1841.

Esto último plantea una situación curiosa y llena de significado político, constitucional e histórico, para el Ejército y para Chile. 


\section{Bibliografía}

\section{Fuentes primarias}

Archivo del Foreign Office, White a Foreign Office, FO 16/23, Nº 15. Valparaíso, 27 de mayo de 1834.

Boletín de las leyes y las órdenes y decretos del gobierno, Libro Tercero, Santiago: Imprenta de la Independencia, Segunda edición, 1839.

Constitución Política del Estado de Chile promulgada el 23 de octubre de 1822. Santiago: Imprenta del Estado, 1822.

Constitución Política del Estado de Chile. Promulgada el 29 de diciembre de 1823. Santiago: Imprenta Nacional, 1823.

Constitución Política de la República de Chile 1828. Santiago: Imprenta de R. Rengifo, 1828.

Constitución Política de la República de Chile Jurada y promulgada el 25 de mayo de 1833. Santiago: Imprenta de la Opinión, 1833.

El Sufragante. 1829.

El Araucano. 1830; 1841.

El Defensor de los Militares Denominados Constitucionales. 1830.

García Huidobro, Cristóbal y Javier Infante, Editores. Muy señor mío...

Un epistolario de Juan Egaña Risco 1801-1833. Santiago: Historia Chilena, 2016.

La Bandera Tricolor. La Serena, 1831.

Los Constitucionales. "Chilenos". Santiago: Imprenta Republicana, 1829.

Prieto, Joaquín. "Proclama del General Prieto a sus soldados". Hoja suelta, Chillán, sde, 24 de octubre de 1829.

Sam Larned a Henry Clay, Santiago, 29 de marzo de 1829. United States of America, State Department, Washington D. C., Dispatches From United States Minister To Chile, 1823-1906, Nº 80.

Sesiones de los Cuerpos Legislativos de la República de Chile 1811 a 1845. Tomo I. Santiago: Imprenta Cervantes, 1887.

Sesiones de los Cuerpos Legislativos de la República de Chile, 1811 a 1845. Tomo XVI. Santiago: Imprenta Cervantes, 1893.

Sesiones de los Cuerpos Legislativos de la República de Chile, 1811 a 1845. Tomo XVIII. Santiago: Imprenta Cervantes, 1897.

Sesiones de los Cuerpos Legislativos de la República de Chile, 1811 a 1845. Tomo XI Santiago: Imprenta Cervantes, 1901.

Tupper, Guillermo. Memorias del Coronel Tupper. Buenos Aires: Editorial Francisco de Aguirre, 1972. 
Valencia Avaria, Luis. Anales de la República. Santiago: Editorial Andrés Bello, 1986.

\section{Fuentes secundarias}

Agüero, Felipe. "Autonomy of the Military in Chile: From Democracy to Authoritarianism", en Democracy Under Siege. New Military Power in Latin America, editado por Augusto Varas. New York-London: Greenwood Press, 1989, 83-96.

Artola, Miguel. Constitucionalismo en la historia. Barcelona: Crítica, 2005.

Barros Arana, Diego. Historia Jeneral de Chile. Santiago: Josefina M. de Palacios, Editora, 1897. Tomo XV.

Barros Arana, Diego. Historia Jeneral de Chile. Santiago: Imprenta Cervantes, 1902. Tomo XVI.

Bravo Lira, Bernardino. "Gobiernos civiles y gobiernos castrenses en Iberoamérica. 1810-1992”, Sociedad y Fuerzas Armadas, 5-6 (1992): 3-35.

Bravo Lira, Bernardino. "Portales", en Portales, el hombre y su obra: la consolidación del gobierno civil, compilado por Bernardino Bravo Lira. Santiago: Editorial Jurídica de Chile, 1989, 341-442.

Cartes, Armando. Concepción contra Chile. Consensos y tensiones regionales en la Patria Vieja. Santiago: Centro de Estudios Bicentenario, 2016.

Cavieres, Eduardo. Sobre la independencia en Chile. El fin del Antiguo Régimen y los orígenes de la representación moderna. Valparaíso: Ediciones Universitarias de Valparaíso, 2012.

Centeno, Miguel Ángel. Blood and debt: war and the nation-state in Latin America. University Park, Penn State University Press, 2002. Collier, Simon. "Cuatro hombres de armas en la formación y la consolidación de la República", en Patriotas y ciudadanos. Santiago: Centro de Estudios para el Desarrollo, 2004, 16-38.

Collier, Simon. Ideas y política de la Independencia chilena, 1808-1833. Santiago: Editorial Andrés Bello, 1977.

Couyoumdjian, Ricardo, Coordinador, y Joaquín Fermandois, Director. Chile. Crisis imperial e independencia, Tomo 1 1808/1830. Madrid: Fundación Mapfre - Taurus, 2010.

Encina, Francisco Antonio. Historia de Chile, Tomo X. Santiago: Editorial Nascimento, Segunda Edición, 1962. 
Errázuriz, Federico. Chile bajo el imperio de la Constitución de 1828. Santiago: Imprenta Chilena, 1861.

Eyzaguirre, Jaime. Ideario y ruta de la emancipación chilena. Santiago: Editorial Universitaria, $24^{a}$ edición [1957, $1^{\mathrm{a}}$ edición], 1996.

Fernández, Enrique. "La institucionalidad jurídico-política chilena entre 1831 y 1931: las bases de su estabilidad", Jahrbuch für Geschichte Lateinamerikas, 40 (2003): 251-276.

Fernández, Joaquín. "Los orígenes de la guardia nacional y la construcción del ciudadano-soldado. Chile, 1823-1833", Mapocho, 56 (2004): 329-352.

Fernández, Joaquín. "Las guerras civiles en Chile", en Historia política de Chile, 1810-2010, editado por Iván Jaksic y Juan Luis Ossa. Tomo I. Prácticas políticas. Santiago: Fondo de Cultura Económica, 2019, 53-82.

García, Gonzalo y Juan Esteban Montes, Subordinación Democrática de los militares. Éxitos y fracasos en Chile. Santiago: Centro de Estudios del Desarrollo, 1994.

Guzmán Brito, Alejandro. "El constitucionalismo revolucionario francés y las cartas fundamentales chilenas del siglo XIX", en La Revolución Francesa y Chile, editado por Ricardo Krebs y Cristián Gazmuri. Santiago: Editorial Universitaria, 1990, 225-245.

Halperin Donghi, Tulio. Reforma y disolución de los imperios ibéricos 1750-1850. Madrid: Alianza, 1985.

Heise, Julio. Años de formación y aprendizaje políticos 1810/1833. Santiago de Chile: Editorial Universitaria, 1978.

Hernández Ponce, Roberto. "La Guardia Nacional de Chile. Apuntes sobre su origen y organización 1808-1848”, Historia, 19 (1984): $53-114$.

Infante, Javier. Autonomía, independencia y república en Chile 18101828. Santiago: Centro de Estudios Bicentenario, 2014.

Jocelyn Holt, Alfredo. La Independencia de Chile. Tradición, Modernización y Mito. Santiago: Planeta/Ariel, 1999.

Johnson, John. The military and society in Latin America. Stanford, Stanford University Press, 1964.

Lieuwen, Edwin. Arms and politics in Latin America. New York: Frederick A. Praeger, 1960.

Lynch, John. Caudillos en Hispanoamérica 1800-1850. Madrid: MAPFRE, 1993. 
Mc Evoy, Carmen y Gabriel Cid, "El republicanismo en Perú y Chile: derroteros y desafíos de un proyecto en América del Sur, 18101895", en América Latina de la Independencia a la crisis del liberalismo 1810-1930, editado por Nuria Tabanera y Marta Bonaudo. Volumen V. Marcial Pons - Prensas de la Universidad de Zaragoza, 2016, 313-336.

Nunn, Frederick. The military in Chilean history. Essays on civil-military relations, 1810-1973. Albuquerque: University of New Mexico Press, 1976.

Ossa, Juan Luis. "La actividad política de Francisco Antonio Pinto: 1823-1828. Notas para una revisión geográfica”, Historia, 40, 1 (2007): 91-128.

Ossa, Juan Luis. Armies, politics and revolution. Chile, 1808-1826. Liverpool: Liverpool University Press, 2014.

Ossa, Juan Luis. "Revolución y construcción republicana en Chile, 1810-1851", en Historia política de Chile, 1810-2010. Tomo I. Prácticas políticas, editado por Iván Jaksic y Juan Luis Ossa. Santiago: Fondo de Cultura Económica, 2017, 23-52.

Pasquino, Gianfranco. "Militarismo", en Diccionario de política, dirigido por Norberto Bobbio, Nicola Matteucci y Gianfranco Pasquino. Madrid: Alianza Editorial, 2007, 962-970.

Peralta, Ariel. "Ejército y mentalidad militar en la historia americana y de Chile en el siglo XIX", Mapocho, 38 (1995): 199-227.

Pinto, Julio y Verónica Valdivia. ¿Chilenos todos? La construcción social de la nación. 1810-1840. Santiago: Lom Ediciones, 2009.

Rojas, Gonzalo. "Portales y la seguridad interior del Estado", en Chile en épocas de crisis. Estudios sobre partidos, ideologías y libertades, Gonzalo Rojas. Santiago: Historia Chilena, 2015, 67-99.

Rolle, Claudio. "Los militares como agentes de la revolución", en La Revolución Francesa y Chile, editado por Ricardo Krebs y Cristián Gazmuri. Santiago: Editorial Universitaria, 1990, 277-301.

Rouquié, Alain. El estado militar en América Latina. Buenos Aires, Emecé, 1984.

Salazar, Gabriel. Construcción de Estado en Chile. 1800-1837. Democracia de los "pueblos". Militarismo ciudadano. Golpismo oligárquico. Santiago: Editorial Sudamericana, 2005.

San Francisco, Alejandro. "Los militares y la política en Chile republicano. Dos siglos con contradicciones, intervenciones y constitucio- 
nes", Anales del Instituto de Chile. Estudios: la política en Chile, 2, XXX (2011): 109-148.

Silva, Fernando editor Historia de la República de Chile 1808-1826.

Volumen 1. El fin de la monarquía y los orígenes de la república.

Santiago: Zig Zag, 2003.

Tupper, Guillermo. Memorias del Coronel Tupper. Buenos Aires, Editorial Francisco de Aguirre, 1972.

Valenzuela, Samuel. Democratización vía reforma: la expansión del sufragio en Chile. Buenos Aires, IDES, 1985.

Varas, Augusto, Agüero, Felipe y Fernando Bustamante, Chile, Democracia, Fuerzas Armadas Santiago, FLACSO, 1980.

Verbal, Valentina. "Las Fuerzas Armadas en la Constitución de 1828.

Una explicación desde las relaciones civiles-militares", Revista Ensayos Militares, 1, 2 (2015): 179-191.

Verbal, Valentina. "Las relaciones civiles-militares en Chile bajo la Constitución de 1823. Una explicación de sus disposiciones y contexto político”, Derecho Público Iberoamericano,7 (2015): 159-199.

Vergara Quiroz, Sergio, Historia Social del Ejército de Chile. Vol. I. Santiago: Universidad de Chile, 1993.

Vergara, Sergio. "Portales y el Ejército", en Portales. El hombre y su obra. La consolidación del gobierno civil, Bernardino Bravo Lira. Santiago: Editorial Jurídica-Andrés Bello, 1989): 87-116.

Vicuña Mackenna, Benjamín. Don Diego Portales. Santiago: Universidad de Chile, 1937.

Villalobos, Sergio, Tradición y reforma en 1810. Santiago: RIL editores, $2^{a}$ edición, 2006.

Zepeda, Cristóbal. "El principio constitucional de obediencia y no deliberación militar en la sublevación de Quillota y el asesinato de don Diego Portales. 1837”, tesis para optar al grado de Licenciado en Derecho, Facultad de Derecho, Pontificia Universidad Católica de Chile. 2011.

Para citar este artículo: San Francisco, Alejandro. "El ejército y la definición de sus principios constitucionales. Obediencia y no deliberación política en Chile, 1829-1830", Historia Caribe Vol. XV No. 36 (Enero-Junio 2020): 235-277 DOI: http://dx.doi.org/10.15648/ hc.36.2020.10 